\title{
Adhesion of Shewanella oneidensis MR-1 to Goethite: A Two- Dimensional Correlation Spectroscopic Study
}

\author{
Wei Yan, ${ }^{\dagger}$ Hongbo Wang, ${ }^{\ddagger}$ and Chuanyong Jing ${ }^{* \dagger}$ \\ ${ }^{\dagger}$ State Key Laboratory of Environmental Chemistry and Ecotoxicology, Research Center for Eco-Environmental Sciences, Chinese \\ Academy of Sciences, Beijing 100085, China \\ ${ }^{\ddagger}$ School of Municipal and Environmental Engineering, Shandong Jianzhu University, Jinan 250101, China
}

Supporting Information

\begin{abstract}
Bacterial adhesion to mineral surfaces is an important but underappreciated process. To decipher the molecular level process and mechanism, the adhesion of Shewanella oneidensis MR-1 cells to goethite was investigated using flow-cell attenuated total reflectance (ATR) Fourier transform infrared (FTIR) spectroscopy coupled with twodimensional correlation spectroscopy (2D-COS) analysis. The FTIR results indicate that bacterial phosphate-moieties play an important role in the formation of mono- and bidentate inner-sphere complexes, whereas carboxylic groups on cell surface only have a minor contribution to its adhesion. The 2D-COS analysis in short-term (0-120 min) and long-term $(2-18 \mathrm{~h})$ stages reveal that the adhesion process was in the following sequence: change in H-bonds of proteins on cell surfaces > formation of monodentate inner-sphere surface complexes $>$ formation

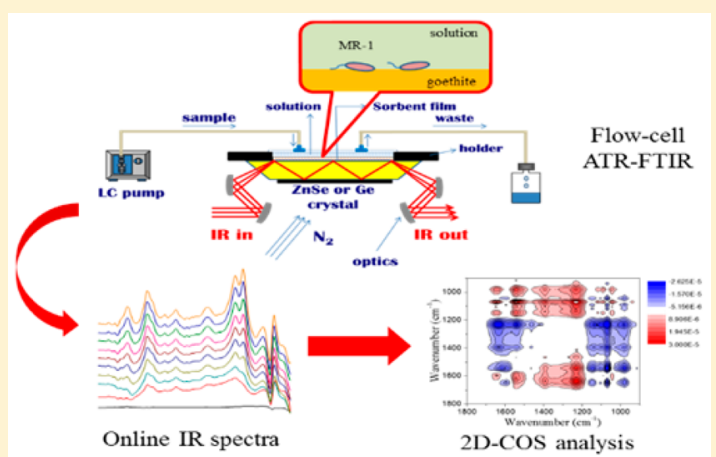
of outer-sphere surface complexes $>$ transformation of protein secondary structure on cell surfaces $>$ formation of additional bridging bidentate surface complexes. In addition, the adhesion of MR-1 cells on goethite was $\mathrm{pH}$ dependent due to $\mathrm{pH}$ impacts on the cell structure and the interface charge. The in situ ATR-FTIR integrated with 2D-COS analysis highlights its great potential in exploring complex surface reactions with microbes involved. These results improve our understanding of microbemineral interactions at the molecular level and have significant implications for a series of biogeochemical processes.
\end{abstract}

\section{INTRODUCTION}

Dissimilatory iron-reducing bacteria (DIRB), which are ubiquitous in terrestrial soils and aquatic environments, play a key role in biogeochemical cycles of iron, carbon, and other elements. ${ }^{1,2}$ Once attached to Fe-bearing minerals such as goethite, DIRB can consume these poorly soluble extracellular substrates as electron acceptors for anaerobic respiration. ${ }^{3-5}$ This process influences the fate of a wide variety of organic and inorganic contaminants associated with iron minerals. ${ }^{6-8}$ Because of the prevalence of DIRB and Fe(III) minerals in the environment, DIRB-mediated transformation of contaminants is considered one of the most promising bioremediation strategies. 6,9

Mounting evidence suggests that the direct electron transfer from DIRB to $\mathrm{Fe}$ (III) minerals is a crucial pathway for microbial extracellular respiration. ${ }^{10}$ Proteins involved in such electron transfer, such as c-type cytochromes of Shewanella oneidensis MR-1, one of the most extensively studied DIRB, are localized in outer membranes of the DIRB. ${ }^{5}$ Thus, adhesion of the DIRB cells to $\mathrm{Fe}(\mathrm{III})$ minerals is a prerequisite for microbial mediated iron redox reactions. However, the molecular-level reaction mechanism at the DIRB-mineral interface has remained enigmatic., ${ }^{9,11}$

The lack of this essential knowledge is mainly due to the complex and heterogeneous cell surfaces of DIRB. DIRB are usually Gram-negative and their cell surface components include various biomolecules such as lipopolysaccharides (LPS), membrane-bound proteins and extracellular polymeric substances (EPS). ${ }^{11-13}$ These components contain various functional groups/moieties (carboxyl, phosphoryl, amide, amino, hydroxyl) that can potentially form covalent bonds with mineral surfaces, leading to complex bacteria-mineral interactions. Recently, the interactions between intact bacterial cells and cell components with $\mathrm{Fe}$ (III) (oxyhydr)oxide surfaces were explored using attenuated total reflectance (ATR) Fourier transform infrared (FTIR) spectroscopy. ${ }^{12,14,15}$ However, the intrinsically low resolution of ATR-FTIR may have difficulty in interpreting the interaction mechanisms at the molecular level. In addition, most of the previous studies focused on the final semiequilibrium stage rather than on the dynamic adhesion process, which indeed is a function of surface cell density. ${ }^{16}$ Nevertheless, various biomolecule-surface complexes may exist with different types of surface covalent bonds or coordination at progressive adhesion stages.

Received: January 6, 2016

Revised: March 29, 2016

Accepted: March 30, 2016

Published: March 31, 2016 
The objective of this study was to explore the molecular-scale interaction of DIRB cells on $\mathrm{Fe}$ (III) oxyhydroxide surfaces using online in situ ATR-FTIR spectroscopy integrated with two-dimensional correlation spectroscopy (2D-COS). 2D-COS is especially suitable for studying the chemical and biological interfacial processes due to its merits of enhanced spectral resolution used to detect subtle changes in IR spectra and its capacity to probe a specific reaction sequence upon external perturbations. ${ }^{17-19}$ The insights gained from this study should improve our knowledge of molecular-level reaction mechanisms at the microbe-mineral interface.

\section{MATERIALS AND METHODS}

Materials. All chemicals were analytical reagent grade or higher and were used without further purification. Milli-Q water (18.2 M $\Omega$ ) was boiled for $60 \mathrm{~min}$ and cooled with $\mathrm{N}_{2}$ gas purging to remove $\mathrm{CO}_{2} . \alpha$-Goethite and Shewanella oneidensis MR-1 were selected as a typical Fe(III) oxyhydroxide and DIRB species, respectively, based on their ubiquitousness in the environment and high importance toward ecological systems.

Goethite was synthesized via iron nitrate hydrolysis as detailed in our previous report. ${ }^{20}$ The BET surface area (84.7 $\mathrm{m}^{2} / \mathrm{g}$ ) was determined with ASAP2000 (Micromeritics Instrument Corp., USA). The point of zero charge (PZC) of goethite was determined to be 8.9 with a Zetasizer Nano ZS (Malvern Instruments, U.K.).

Shewanella oneidensis MR-1 was grown aerobically from frozen $\left(-80^{\circ} \mathrm{C}\right)$ stock to lag-log phase in a Luria-Bertani (LB) broth at $30^{\circ} \mathrm{C}$ as evidenced by its $\mathrm{OD}_{600}$ of $2.2-2.8$. Then, the cells were harvested by centrifugation at $2100 \mathrm{~g}$ for $15 \mathrm{~min}$ at 4 ${ }^{\circ} \mathrm{C}$ and washed at least three times with sterile $0.1 \mathrm{M} \mathrm{NaCl}$ solution at investigated $\mathrm{pH}$ to avoid the disturbance from residue substances from LB broth and dissolved ligands leached from MR-1 cells. Finally, the cells were resuspended in an appropriate volume of $0.1 \mathrm{M} \mathrm{NaCl}\left(1 \times 10^{10}\right.$ cells $\left.\mathrm{mL}^{-1}\right)$ at desired $\mathrm{pH}$ for following ATR-FTIR measurements. All growth media and containers used in this study were autoclaved prior to incubation.

ATR-FTIR Measurements. ATR-FTIR measurements were performed using a Thermo-Nicolet Nexus 6700 FTIR spectrometer equipped with a liquid-nitrogen cooled MCT detector. The IR spectra were collected using a horizontal attenuated total reflectance (HATR) cell (PIKE Tech) with a $45^{\circ} \mathrm{ZnSe}$ ATR crystal. A total of 1000 and 256 scans were recorded over $1800-800 \mathrm{~cm}^{-1}$ at a resolution of $4 \mathrm{~cm}^{-1}$ for each spectrum of normal static and in situ flow cell ATR-FTIR, respectively.

The ATR-FTIR spectra of the MR-1 suspension samples $\left(\approx 10^{10}\right.$ cells $\left.\mathrm{mL}^{-1}\right)$ at $\mathrm{pH} 5$ to 9 were obtained by subtracting the spectrum of bacteria-free background electrolyte solutions at the same $\mathrm{pH}$ from the MR-1 spectrum.

In situ flow cell ATR-FTIR measurements of bacterial adhesion to goethite were conducted following our reported procedure with minor modifications. ${ }^{21,22}$ The details are provided in the Supporting Information (SI). During each experiment, the MR-1 cells in the solution were stirred with a magnetic stir bar to ensure uniform mixing, and the $\mathrm{pH}$ was kept constant using either $\mathrm{NaOH}$ or $\mathrm{HCl}$. All the ATR-FTIR measurements were under nongrowth condition of MR-1 cells. The surface interactions with living cells should be worthy of further study.

The number of scan and the rate of MR-1 flow are two important factors for the flow cell ATR-FTIR analysis. Too fast flow may cause much MR-1 cells deposit on the goethite surface per unit time, resulting in the multilayer adhesion on goethite, and too long time in data collection may fail to catch the quick spectral changes. In this study, we select 256 scans, which ensure the spectral quality and do not consume too much time $(2.5 \mathrm{~min})$. The rate of fluid flow was set at $2 \mathrm{~mL} /$ min. The dimension of ZnSe ATR cell surface is about $7 \mathrm{~cm}^{2}$. The cell density of fluid flow is about $10^{6}$ cells $\mathrm{mL}^{-1}$. We assume the average size of the cell is about $1 \mu \mathrm{m}^{2}$. Then, for one signal collection, in the worst case, the occupied surface area of cells is $2(\mathrm{~mL} / \mathrm{min}) \times 2.5(\mathrm{~min}) \times 10^{6}$ cells $\mathrm{mL}^{-1} \times$ $10^{-8} \mathrm{~cm}^{2}=0.05 \mathrm{~cm}^{2}$, far smaller than the dimension of $\mathrm{ZnSe}$ ATR cell surface $\left(7 \mathrm{~cm}^{2}\right)$.

2D-COS Analysis. After smooth and baseline correction for the IR spectra using Omnic 8.0 software, 2D-COS analysis was performed using 2Dshige software (Shigeaki Morita, Japan). The sequential order of intensity change between bands $v_{1}$ and $v_{2}$ can be obtained from the sign of the synchronous correlation peak $\Phi\left(v_{1}, v_{2}\right)$ and asynchronous correlation peak $\Psi\left(v_{1}, v_{2}\right)$ under well-established principles. ${ }^{21,23}$ Briefly, the change in the spectral intensity at band $v_{1}$ occurs prior to that at $v_{2}$ if $\Phi\left(v_{1}\right.$, $\left.v_{2}\right)$ and $\Psi\left(v_{1}, v_{2}\right)$ have the same signs; while the order is reversed if $\Phi\left(v_{1}, v_{2}\right)$ and $\Psi\left(v_{1}, v_{2}\right)$ have opposite signs. The changes at $v_{1}$ and $v_{2}$ occur simultaneously if $\Psi\left(v_{1}, v_{2}\right)$ is zero. More detailed introduction of $2 \mathrm{D}$-COS analysis is provided in the SI.

For a better identification of peaks, the peak fittings of all IR spectra were carried out with Peakfit v.4.12 software using the second derivative fitting algorithm. The goodness of fit $\mathrm{R}$ factor in all of the fitted spectra was greater than 0.999 .

\section{RESULTS AND DISCUSSION}

Mineral-Free MR-1 Cells. The physiological $\mathrm{pH}$ range of Shewanella cell is about $6-10 .{ }^{24}$ However, because the surface functional groups of MR-1 cells play an important role in interfacial interactions, we mainly focused on these functional groups rather than the cell metabolism. Based on the $\mathrm{pH}$ range of $\mathrm{ZnSe}$ crystal, the reactions at $\mathrm{pH} \mathrm{5-9}$ were investigated.

The mineral-free MR-1 cells in the $\mathrm{pH}$ range 5-9 exhibits similar ATR-FTIR bands of absorbance, except the obvious changes in the intensity of bands in the range $1730-1710 \mathrm{~cm}^{-1}$ (Figure 1). Because MR-1 lacks EPS, the ATR-FTIR spectra mainly reflects the various components on cell walls (Table

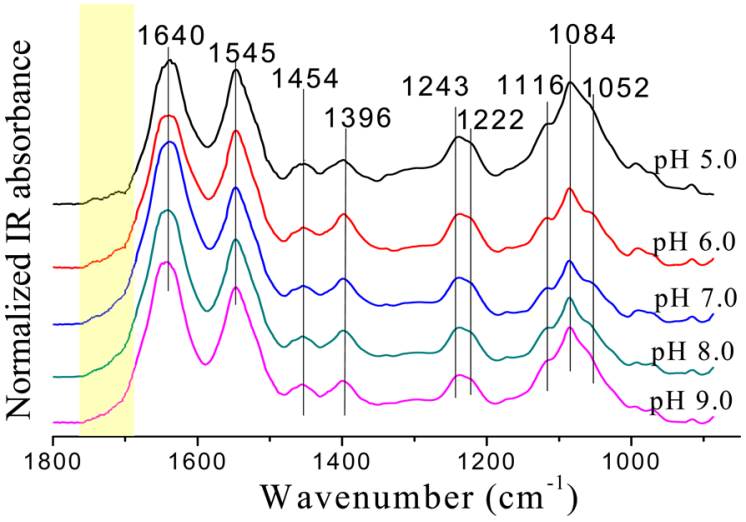

Figure 1. ATR-FTIR spectra of MR-1 suspensions with a cell density of $10^{10}$ cells $\mathrm{mL}^{-1}$ for $\mathrm{pH}$ values 5 to 9 . All FTIR spectra were normalized, with the relative intensity of the strongest amide I band peak observed at $1640 \mathrm{~cm}^{-1}$. 
S1). ${ }^{25}$ Thus, the result of ATR-FTIR spectra indicates that $\mathrm{pH}$ does not have a significant effect on the type and distribution of functional groups on MR-1 cell surfaces, which is consistent with previous studies. ${ }^{12}$ The observable change in the FTIR spectra was the disappearance of bands in the range 1730-1710 $\mathrm{cm}^{-1}$ with increasing $\mathrm{pH}$, due to the deprotonation of carboxyl groups at cell surfaces (yellow region in Figure 1). The carboxyl group was therefore suspected to be an active functional group interacting with goethite surfaces which motivates further investigation.

MR-1 Adhesion on Goethite. The attachment of MR-1 cells to goethite at $\mathrm{pH} 5,7$, and 9 was investigated and the spectra at each of the equilibria are shown in Figure 2. For each

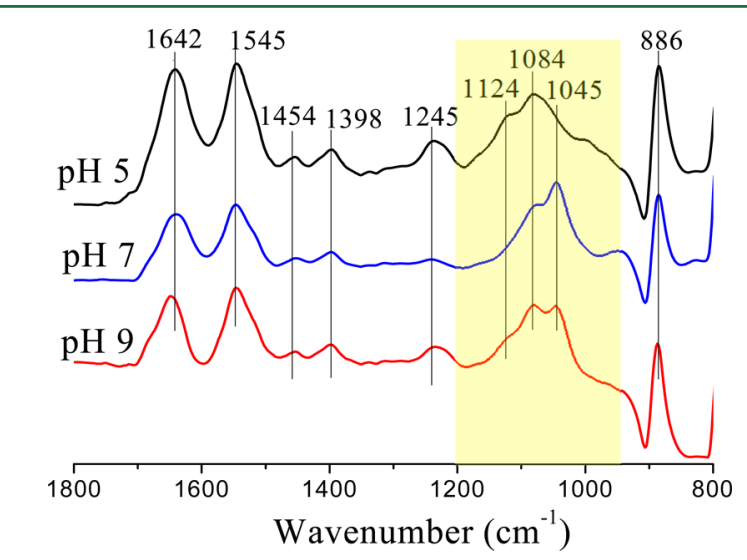

Figure 2. ATR-FTIR spectra of attached MR-1 cells on goethite at $\mathrm{pH}$ 5,7 , and 9 after $16 \mathrm{~h}$ adhesion equilibrium.

investigated $\mathrm{pH}$, however, carboxyl groups at cell surfaces were not involved in the formation of covalent bonds at the goethite surface, as evidenced by the unchanged carboxylate $\mathrm{COO}^{-}$ symmetric stretch $\nu_{s}\left(\mathrm{COO}^{-}\right.$) at $1396 \mathrm{~cm}^{-1}$ (Figure 2, Figure S1). Thus, carboxyl groups may only have a minor contribution to the cell attachment. Other functional groups such as sulfhydryl group, which may be important for some microorganisms, were not anticipated to play a role in the MR-1 cell adhesion, nor where they observed in the FTIR spectra. Conversely, polysaccharide and phosphate groups in the range of $1200-900 \mathrm{~cm}^{-1}$ (yellow region in Figure 2, Figure S1) ${ }^{11}$ exhibited prominent changes upon adhesion at different $\mathrm{pH}$ values. This result indicates that the phosphate and polysaccharide moieties may play an import role in the interfacial interactions. The overlap of IR peaks in this range highlights the necessity for further deconvolution.

Figure 3 shows the deconvoluted IR spectra based on second derivative analysis (Figure S2), and the peak assignments are summarized in Table 1. Compared to that of mineral-free MR-1
Table 1. Deconvoluted FTIR Vibrational Frequencies and Assignments for P-Moieties of Adsorbed MR-1 Cells

\begin{tabular}{ll}
$\begin{array}{c}\text { wavenumber } \\
\left(\mathrm{cm}^{-1}\right)\end{array}$ & \multicolumn{1}{c}{$\quad$ IR band assignment } \\
$1150-1160$ & $\nu(\mathrm{P}-\mathrm{O})$ of phosphoryl surface complexes ${ }^{12}$ \\
$1110-1120$ & $\nu(\mathrm{P}=\mathrm{O})$ of bridging bidentate surface complexes ${ }^{28}$ \\
$1080-1085$ & $\nu_{\mathrm{s}}\left(\mathrm{PO}_{2}^{-}\right)$of monodentate surface complexes ${ }^{12}$ \\
1045 & $v(\mathrm{P}-\mathrm{OFe})$ monodentate surface complexes \\
$995-1011,25$ & $v_{\text {as }}\left(\mathrm{P}-(\mathrm{OFe})_{2}\right.$ of bridging bidentate surface \\
complexes $^{28^{2}}$ & $v(\mathrm{P}-\mathrm{OFe})$ or $v(\mathrm{P}-\mathrm{OH})^{12,28}$ \\
$950-955$ & $v_{\mathrm{s}}\left(\mathrm{P}-(\mathrm{OFe})_{2}\right.$ of bridging bidentate surface complexes ${ }^{28}$ \\
$927-930$ & $\delta(\mathrm{OH})$ of goethite \\
886 &
\end{tabular}

cells (Figure S3), a prominent band at $\sim 1045 \mathrm{~cm}^{-1}$ was resolved at all $\mathrm{pH}$. Because this intense peak was absent in MR1 cells (Figure S3), its occurrence is likely associated with the chemical bonding of MR-1 cells to goethite surfaces. Consistent with previous studies, ${ }^{11,26,27}$ the band at $1045 \mathrm{~cm}^{-1}$ can be assigned as $\mathrm{P}-\mathrm{OFe}$ stretching vibrations $(v(\mathrm{P}-\mathrm{OFe}))$. In addition to the band at $1045 \mathrm{~cm}^{-1}$, several new vibrations involving phosphate moieties (phosphonate, phosphoryl, etc.) were resolved including $996\left(v_{\text {as }}\left(\mathrm{P}-(\mathrm{OFe})_{2}\right)\right.$ and $930 \mathrm{~cm}^{-1}$ $\left(v_{s}\left(\mathrm{P}-(\mathrm{OFe})_{2}\right)^{28,29}\right.$ The presence of these bands clearly demonstrates that the bacterial P-moieties were involved in the formation of inner-sphere complexes with goethite surfaces, contributing significantly to the MR-1 adhesion.

Online in Situ ATR-FTIR Study. A major limitation in the static ATR-FTIR analysis on the final state, however, is its incapability to reflect the dynamic change of the interfacial reactions during the adhesion process. In fact, the bacterial adhesion to the goethite surface undergoes various interactions depending on the adhered cell densities of MR-1 on goethite surfaces. The interactions, in turn, may have an impact on the surface structures of MR-1 cells. To elucidate the dynamics of the adhesion process, online in situ flow cell ATR-FTIR analyses were performed at various $\mathrm{pH}$ values. Since the entire adhesion process exhibited a fast attachment at an initial stage ( 0 to $\sim 120 \mathrm{~min}$ ) followed by a relatively slower one from 2 to $18 \mathrm{~h}$ (Figure S4), the short- and long-term surface reactions were investigated separately.

The ATR-FTIR spectra clearly reveal two pronounced changes upon the adhesion of MR-1 cells in the $\mathrm{pH}$ range 5-9 (Figure 4). The first one was in the region 1200-900 $\mathrm{cm}^{-1}$. The peak intensities varied significantly at different $\mathrm{pH}$ and time values (Figure 4), indicating that bacterial P-moieties are involved in multiple interactions with goethite surfaces during the adhesion process.

Previous studies on orthophosphate adsorption to $\mathrm{Fe}(\mathrm{III})$ oxyhydroxide conclude that $\mathrm{pH}$ and surface loading have a

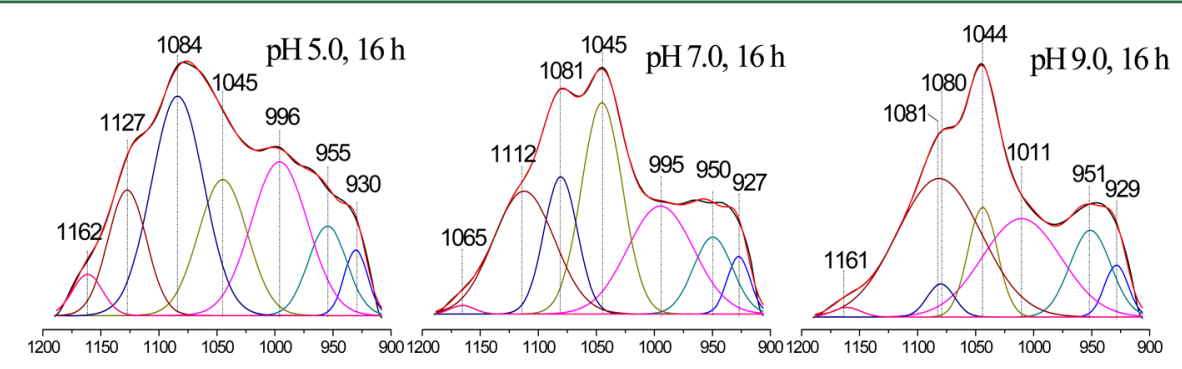

Figure 3. Deconvoluted ATR-FTIR spectra of MR-1 adsorbed to the goethite surface at pH 5, 7, and 9 at equilibrium. 


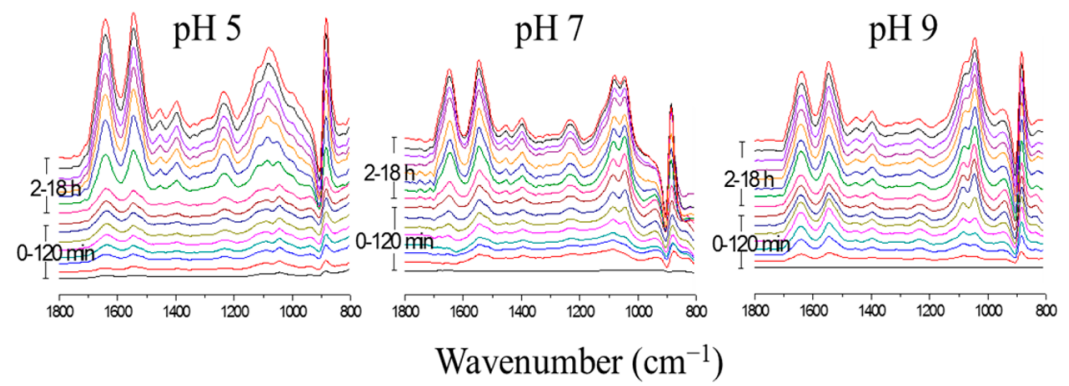

Figure 4. ATR-FTIR spectra for MR-1 adhesion to goethite at short-term (0-120 min) and long-term (2-18 h) at $\mathrm{pH} \mathrm{5,} \mathrm{7,} \mathrm{and} 9$.
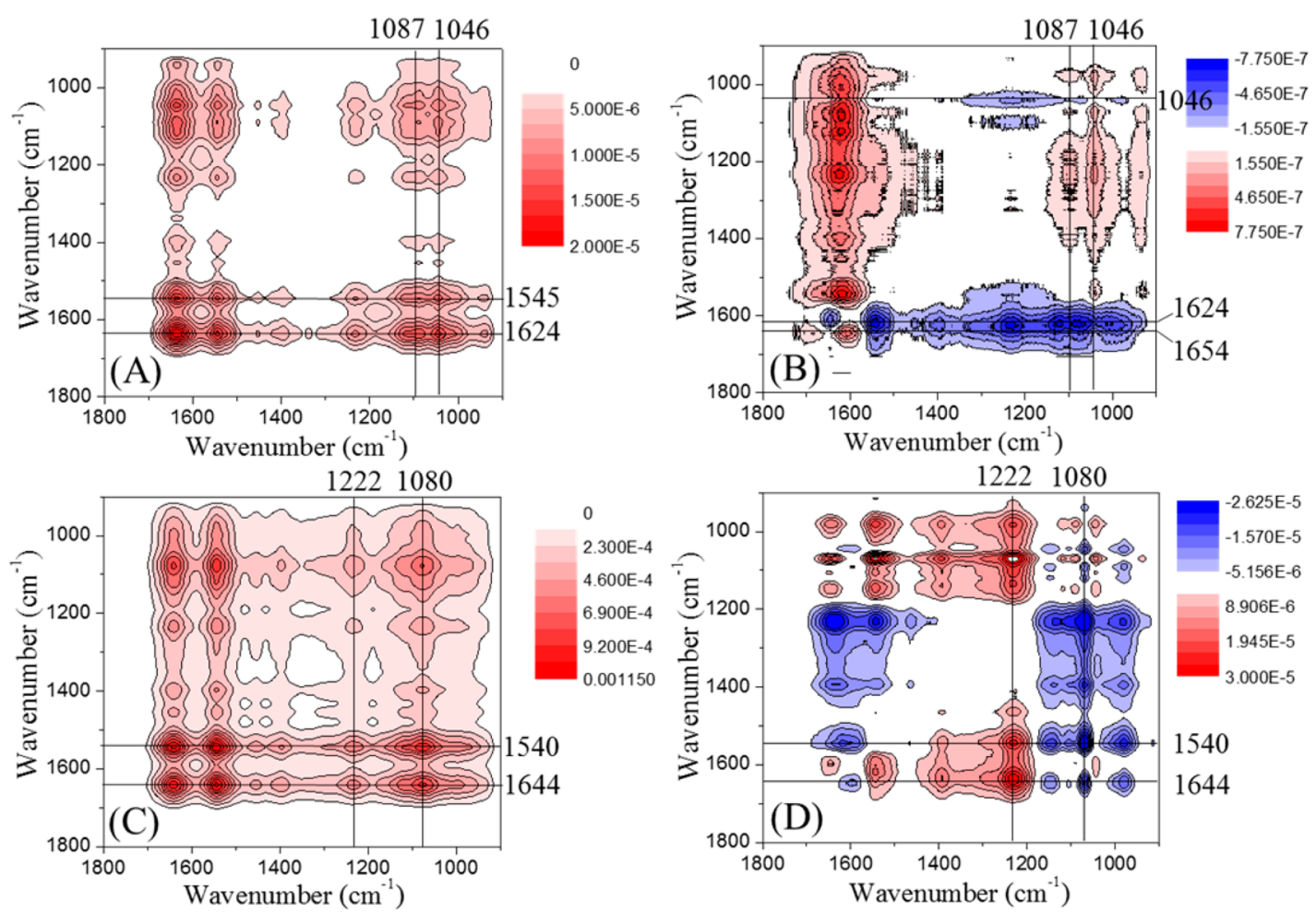

Figure 5. Synchronous (A, C) and asynchronous (B, D) 2D correlation contour maps of time-dependent ATR-FTIR spectra for the short-term (A, B) and long-term (C, D) adhesion of MR-1 cells to goethite at $\mathrm{pH}$ 5. The blue (red) regions were defined as negative (positive) correlation intensities.

great impact on $\mathrm{PO}_{4}$ surface configuration. ${ }^{28,29} \mathrm{PO}_{4}$ forms a monodentate monoprotonate surface complex at high $\mathrm{pH}$ values and low $\mathrm{PO}_{4}$ loadings, ${ }^{29}$ characterized by the bands at $1080\left(v_{\text {as }}\left(\mathrm{PO}_{2}\right), 1050\left(v_{\mathrm{s}}\left(\mathrm{PO}_{2}\right)\right)\right.$, and $950 \mathrm{~cm}^{-1}(v(\mathrm{P}-\mathrm{OFe})$ or $v(\mathrm{P}-\mathrm{OH}))$. The decrease in $\mathrm{pH}$ and increase in $\mathrm{PO}_{4}$ loading induces the formation of an additional bridging bidentate surface complex, resulting in the bands at 1120 $(v(\mathrm{P}=\mathrm{O})), 1006\left(v_{\text {as }}\left(\mathrm{P}-(\mathrm{OFe})_{2}\right), 982 v(\mathrm{P}-\mathrm{OH})\right)$, and 925 $\mathrm{cm}^{-1}\left(v_{\mathrm{s}}\left(\mathrm{P}-(\mathrm{OFe})_{2}\right)\right.$.

Different from the above-mentioned studies, which only involved orthophosphate species, the exterior of bacterial cells contains various phosphate species and phosphoryl groups. Our deconvoluted ATR-FTIR spectra resolved bands for both monodentate and bridging bidentate surface complexes in short-term (Figure S5) and long-term (Figure 3) reactions for $\mathrm{pH}$ values 5-9. Notably, a nonuniform increase in band intensity was observed, for example, $v(\mathrm{P}-\mathrm{OFe})$ at $1450 \mathrm{~cm}^{-1}$ vs $v_{\text {as }}\left(\mathrm{PO}_{2}\right)$ at $1084 \mathrm{~cm}^{-1}$, suggesting different reaction sequences for various surface complexes.
The second pronounced change was observed in the 1800$1500 \mathrm{~cm}^{-1}$ region, including vibrations of bacterial proteins amide I and II at about 1640 and $1545 \mathrm{~cm}^{-1}$, respectively (Figure 4). The amide I mainly represents the $\mathrm{C}=\mathrm{O}$ stretching vibrations of peptide groups, and the amide II is ascribed to the bending vibrations of $\mathrm{N}-\mathrm{H}$ and $\mathrm{C}-\mathrm{N}$ in the amide. Because of the high sensitivity of amide I to the protein secondary structure $(\alpha$-helices, $\beta$-sheets, turns, and disordered structures), ${ }^{32}$ the ratio in the peak intensity of amide I: amide II is a good indicator to reflect the change in protein secondary structures. ${ }^{11,33}$ In this study, this amide I: amide II ratio varied substantially in the $\mathrm{pH}$ range 5-9 at an initial stage (Figure S6), and then converged with the increasing adhesion time, which was probably due to multilayer adhesion of MR-1 cells. This observation strongly suggests that surficial proteins of MR-1 interacted with goethite surfaces, which consequently led to the alteration of their structural conformation.

Unfortunately, the online in situ ATR-FTIR analysis can identify neither these highly overlapped protein secondary structures nor the reaction sequence of various surface 
complexes during the adhesion process, which necessitates data interpretation using 2D-COS analysis.

2D-COS Analysis. For a complicated system such as the bacteria-mineral interface, molecules with different origins may have overlapping vibrational peaks which cannot be distinguished with deconvolution. Fortunately, these overlapping peaks may have different responses to the external perturbations during the dynamic adhesion process. Such a delicate but important difference in response to interaction sequences of MR-1 cells on goethite can be better understood with $2 \mathrm{D}$-COS analysis.

Figure 5 shows the synchronous and asynchronous 2D correlation contour maps of IR spectra at $\mathrm{pH}$ 5. All autopeaks along the diagonal were positive in synchronous maps (Figure $5 A, C)$. The cross peaks in synchronous maps reflect the bands with coupled, or related origins, and the positive sign suggests the same direction of change in band intensity. The result reveals that major IR peaks underwent simultaneous changes during the adhesion process.

Notably, synchronous maps in 2D-COS provide more detailed information about protein structural change than normal ATR-FTIR. For example, the cross peaks correlated to $1624 \mathrm{~cm}^{-1}$ during the short-term adhesion (Figure 5A) shifted to $1644 \mathrm{~cm}^{-1}$ during the long-term adhesion (Figure 5C), which is consistent with the result of second derivative to the amide I of adsorbed MR-1cell and its deconvoluted ATR-FTIR spectra (Figure S7) This peak shift can be attributed to the change in protein secondary structure upon adhesion. Usually, the $\alpha$-helix vibrations of proteins occur between 1658 and 1650 $\mathrm{cm}^{-1}, \beta$-sheet between 1640 (parallel $\beta$-sheet) and $1620 \mathrm{~cm}^{-1}$ (antiparallel $\beta$-sheet), and random coil at about $1646 \mathrm{~cm}^{-1}$. 34

The change in protein secondary structure is mainly reflected in the length of $\mathrm{H}$-bond connecting the $\mathrm{C}=\mathrm{O}$ groups in a polypeptide chain. A lower wavenumber generally indicates a shorter atomic distance and a stronger H-bond. ${ }^{35}$ The slightly acidic condition ( $\mathrm{pH} \mathrm{5}$ ) facilitates the formation of an H-bond between the carbonyl group and amide within the protein, enabling the protein structure to become an antiparallel $\beta$-sheet $\left(1624 \mathrm{~cm}^{-1}\right)$. This protein structure was observed with the lowest frequency in an initial adhesion stage (Figure 5A).

Throughout the course of adhesion, interfacial interactions disturbed the original $\mathrm{H}$-bonding and converted the protein structure from antiparallel $\beta$-sheet $\left(1624 \mathrm{~cm}^{-1}\right)$ to either parallel $\beta$-sheet or random coil $\left(1644 \mathrm{~cm}^{-1}\right.$, Figure $\left.5 \mathrm{C}\right)$. This result demonstrates that the adhesion to goethite influences the $\beta$-strands of cell surface proteins and consequently alter their configurations. The adhesion process is complicated by structural changes in surface proteins and the formation of multiple P-moieties surface complexes. To decipher which interaction plays an important role in a certain adhesion stage, further exploration of the surface reaction sequences is needed.

Because of the capacity to probe a specific reaction sequence upon external perturbations, asynchronous analysis was performed to identify specific reaction sequences taking place at the bacteria-mineral interface and the results are shown in Figure 5B. Six negative cross peaks were observed at 1540, 1396, 1222, 1087, 1046, and 980/1624 $\mathrm{cm}^{-1}$. According to Noda's rule, ${ }^{22}$ the spectral change at $1624 \mathrm{~cm}^{-1}$ occurred prior to other cross peaks, indicating that the intermolecular and intramolecular $\mathrm{H}$-bonds of proteins at cell surfaces were more susceptible to interfacial interactions than other functional groups. Furthermore, a new cross peak at $1654 / 1610 \mathrm{~cm}^{-1}$ was resolved in the asynchronous map (Figure 5B), which was masked by the strong band at $1624 \mathrm{~cm}^{-1}$ in the synchronous map. This result implies that some of the $\beta$-sheet proteins have converted to the $\alpha$-helix structure after long-term adhesion.

Furthermore, 2D-COS analysis reveals the reaction sequences for other functional groups. For example, during the shortterm adhesion, several cross peaks were observed (Figure $5 \mathrm{~B}, \mathrm{D}$ ). The sign of cross peaks in the asynchronous map (Table S2) indicated a sequence of the interactions of MR-1 cells to the goethite surface as follows: $\beta$-sheet $\left(1624 \mathrm{~cm}^{-1}\right)>v(\mathrm{P}-$ OFe $)\left(1046 \mathrm{~cm}^{-1}\right)>v_{\mathrm{s}}\left(\mathrm{PO}_{2}\right)\left(1087 \mathrm{~cm}^{-1}\right)>v_{\mathrm{s}}\left(\mathrm{COO}^{-}\right)(1396$ $\left.\mathrm{cm}^{-1}\right)$. Similarly, the sign of cross peaks in the asynchronous map for the long-term adhesion (Table S3) indicated a sequence of the interactions as follows: $v_{s}\left(\mathrm{COO}^{-}\right)(1396$ $\left.\mathrm{cm}^{-1}\right), v_{\text {as }}\left(\mathrm{PO}_{2}\right)\left(1222 \mathrm{~cm}^{-1}\right)>\mathrm{N}-\mathrm{H}$ bending of amide II $\left(1540 \mathrm{~cm}^{-1}\right)>$ random coil of amide $\mathrm{I}\left(1644 \mathrm{~cm}^{-1}\right)>v(\mathrm{P}=\mathrm{O})$ $\left(1126 \mathrm{~cm}^{-1}\right), v_{\mathrm{s}}\left(\mathrm{P}-(\mathrm{OFe})_{2}\left(980 \mathrm{~cm}^{-1}\right)\right.$.

On the basis of $2 \mathrm{D}-\mathrm{COS}$ analysis, the adhesion process at $\mathrm{pH}$ 5 can be proposed as follows: when MR-1 cells approach the goethite surface, the interfacial interactions changes the protein secondary structure of cell surface and breaks the intrinsic $\mathrm{H}$ bonds within protein biomolecules. Then, phosphate groups on each cell surface form monodentate inner-sphere surface complexes on goethite. Subsequently, outer-sphere surface complexes can also form via electrostatic interactions between the negative bacterial deprotonated phosphate groups, carboxyl groups, and positive protonated goethite surfaces. With an increase in adhesion time, the protein secondary structure can gradually transform from $\beta$-sheet to $\alpha$-helix and random coil. Finally, additional bridging bidentate surface complexes may form with an increase in cell loading.

Similarly, the adhesion of MR-1 cells to goethite under neutral ( $\mathrm{pH} \mathrm{7,} \mathrm{Figure} \mathrm{S8)} \mathrm{and} \mathrm{alkaline} \mathrm{(} \mathrm{pH} \mathrm{9,} \mathrm{Figure} \mathrm{S9)}$ conditions was also investigated using $2 \mathrm{D}-\mathrm{COS}$ analysis. According to the sign of 2D-COS (Table S4), at $\mathrm{pH} \mathrm{7,} \mathrm{the}$ order of band changes followed $v_{\mathrm{s}}\left(\mathrm{COO}^{-}\right)\left(1396 \mathrm{~cm}^{-1}\right), \mathrm{N}-\mathrm{H}$ bending of amide II $\left(1540 \mathrm{~cm}^{-1}\right)>v_{\mathrm{s}}\left(\mathrm{PO}_{2}\right)\left(1083 \mathrm{~cm}^{-1}\right)>$ $v(\mathrm{P}-\mathrm{OFe})\left(1045 \mathrm{~cm}^{-1}\right)$. With an increase in adhesion time, the protein secondary structure of the bacteria transformed from random coil $\left(1644 \mathrm{~cm}^{-1}\right)$ to $\alpha$-helix $\left(1654 \mathrm{~cm}^{-1}\right)$, and the sequential order became $\alpha$-helix $\left(1654 \mathrm{~cm}^{-1}\right)>v_{\mathrm{s}}\left(\mathrm{COO}^{-}\right)$ $\left(1394 \mathrm{~cm}^{-1}\right), \mathrm{N}-\mathrm{H}$ bending of amide II $\left(1540 \mathrm{~cm}^{-1}\right)>v(\mathrm{P}-$ OFe $)\left(1045 \mathrm{~cm}^{-1}\right), v_{\mathrm{s}}\left(\mathrm{PO}_{2}\right)\left(1081 \mathrm{~cm}^{-1}\right)>v_{\mathrm{s}}\left(\mathrm{COO}^{-}\right)(1394$ $\mathrm{cm}^{-1}$ ) (Table S5). At $\mathrm{pH} 9$, the sign of 2D-COS (Table S6) suggested the sequential order in band change similar to that at $\mathrm{pH} 7$ for short-term-adhesion, indicating the same initial interaction mechanisms. On the contrary, sequential order for long-term adhesion at $\mathrm{pH} 9$ was in stark contrast with that at $\mathrm{pH} 7$ (Table S7): $v_{\mathrm{s}}\left(\mathrm{COO}^{-}\right)\left(1396 \mathrm{~cm}^{-1}\right)>v_{\mathrm{s}}\left(\mathrm{PO}_{2}\right)(1080$ $\left.\mathrm{cm}^{-1}\right)>\mathrm{N}-\mathrm{H}$ bending of amide II $\left(1540 \mathrm{~cm}^{-1}\right)$.

The 2D-COS analysis suggests that the adhesion of MR-1 cells on goethite is highly $\mathrm{pH}$ dependent. The primary reason for such $\mathrm{pH}$ dependence is that the surface structure of bacterial cells is a function of $\mathrm{pH} .{ }^{35}$ Some biomolecules, such as LPS and proteins at the cell surface and outer membrane, are likely to aggregate via intramolecular $\mathrm{H}$-bonds under acidic conditions. Elevated $\mathrm{pH}$ could break the H-bonds and free the macromolecules. As a result, several initially unavailable functional groups on the proteins and LPS, such as phosphate, amino, and carboxylic acid groups, are readily available for surface reactions. Thus, the reaction order at high $\mathrm{pH}$ was different from that at low $\mathrm{pH}$.

In addition, $\mathrm{pH}$ has an impact on electrostatic interactions between MR-1 cells and goethite. The point of zero charge 
(PZC) of goethite is $8.9,^{20}$ suggesting goethite is positively charged under acidic and neutral conditions. On the other hand, MR-1 is negatively charged due to its functional groups. ${ }^{12}$ The strong electrostatic attractions between goethite and MR-1 cells at low $\mathrm{pH}$ should decrease as $\mathrm{pH}$ increases. Therefore, the change in $\mathrm{pH}$ greatly influences the strength of electrostatic interaction, H-binding, and the amount of attached cells.

Environmental Significance. Our results provide new insights into the molecular-level reaction mechanism at the DIRB-mineral interface, which impacts a series of biogeochemical processes. First of all, surface proteins on MR-1 cells trigger reactions at the microbe-mineral interface. The $\mathrm{pH}$ controls the protein secondary structure and aggregation, leading to different reaction sequences and mechanisms. In addition, the $\mathrm{pH}$ also determines the affinity of MR-1 cells to goethite surface due to the electrostatic effects. Thus, $\mathrm{pH}$ is particularly important in evaluating the biological reactivity and transformation of $\mathrm{Fe}$ (III) minerals with attached pollutants.

Our work also demonstrates that the P-moieties on an MR-1 cell surface contribute to its adhesion via various inner-sphere complexes, which are a function of the bacterial cell density. Thus, the coexisting anions, such as free phosphate, silicate, may compete, block the access of, and even displace the bacteria on mineral surfaces. Such a phenomenon has been observed on inhibited bioreduction of lepidocrocite $(\gamma$ $\mathrm{FeOOH}),{ }^{36}$ and highly impacts the fate and transport of pollutants associated with minerals. Considering the great variability in the binding strength of various P-moieties in surface complexation, the strength of the anion effect is quite different, which makes the adhesion process of crucial importance in the environment.

\section{ASSOCIATED CONTENT}

\section{S Supporting Information}

The Supporting Information is available free of charge on the ACS Publications website at DOI: 10.1021/acs.est.6b00066.

Details of in situ flow cell ATR-FTIR measurements, 2DCOS analysis, IR peak intensities as a function of reaction time for the adsorption of MR-1 cells on goethite, peak intensity ratios of amide I to amide II, second derivative spectra of adsorbed and mineral-free MR-1, signs of each cross-peak in the synchronous and asynchronous correlation contour maps of MR-1 cells on goethite at $\mathrm{pH}$ 5, 7, 9 (PDF).

\section{AUTHOR INFORMATION}

\section{Corresponding Author}

*Dr. Chuanyong Jing. Tel: +86 106284 9523. E-mail: cyjing@ rcees.ac.cn.

\section{Notes}

The authors declare no competing financial interest.

\section{ACKNOWLEDGMENTS}

We acknowledge the financial support of the National Key Basic Research Program of China (2014CB441102), the Strategic Priority Research Program of the Chinese Academy of Sciences (XDB14020301), the National Natural Science Foundation of China (21477144, 41373123, and 41425016), and Young Scientists Fund of RCEES (RCEES-QN20130017F).

\section{REFERENCES}

(1) Kappler, A.; Straub, K. L. Geomicrobiological cycling of iron. Rev. Mineral. Geochem. 2005, 59, 85-108.

(2) Melton, E. D.; Swanner, E. D.; Behrens, S.; Schmidt, C.; Kappler, A. The interplay of microbially mediated and abiotic reactions in the biogeochemical Fe cycle. Nat. Rev. Microbiol. 2014, 12, 797-808.

(3) Flynn, T. M.; O’Loughlin, E. J.; Mishra, B.; DiChristina, T. J.; Kemner, K. M. Sulfur-mediated electron shuttling during bacterial iron reduction. Science 2014, 344, 1039-1042.

(4) Wu, T.; Shelobolina, E.; Xu, H.; Konishi, H.; Kukkadapu, R.; Roden, E. E. Isolation and microbial reduction of $\mathrm{Fe}(\mathrm{III})$ phyllosilicates from subsurface sediments. Environ. Sci. Technol. 2012, 46 (21), 11618-11626.

(5) Gralnick, J. A.; Newman, D. K. Extracellular respiration. Mol. Microbiol. 2007, 65, 1-11.

(6) Van der Zee, F. R; Cervantes, F. J. Impact and application of electron shuttles on the redox (bio)transformation of contaminants: A review. Biotechnol. Adv. 2009, 27, 256-277.

(7) Roden, E. E.; Kappler, A.; Bauer, I.; Jiang, J.; Paul, A.; Stoesser, R.; Konishi, H.; Xu, H. Extracellular electron transfer through microbial reduction of solid-phase humic substances. Nat. Geosci. 2010, 3, 417-421.

(8) Williamson, A. J.; Morris, K.; Law, G. T. W.; Rizoulis, A.; Charnock, J. M.; Lloyd, J. R. Microbial reduction of U(VI) under alkaline conditions: Implications for radioactive waste geodisposal. Environ. Sci. Technol. 2014, 48, 13549-13556.

(9) Borch, T.; Kretzschmar, R.; Kappler, A.; Van Cappellen, P.; Ginder-Vogel, M.; Voegelin, A.; Campbell, K. Biogeochemical redox processes and their impact on contaminant dynamics. Environ. Sci. Technol. 2010, 44, 15-23.

(10) Shi, L.; Squier, T. C.; Zachara, J. M.; Fredrickson, J. K. Respiration of metal (hydr)oxides by Shewanella and Geobacter: a key role for multihaem c-type cytochromes. Mol. Microbiol. 2007, 65, 1220.

(11) Parikh, S. J.; Chorover, J. ATR-FTIR spectroscopy reveals bond formation during bacterial adhesion to iron oxide. Langmuir 2006, 22, $8492-8500$.

(12) Elzinga, E. J.; Huang, J. H.; Chorover, J.; Kretzschmar, R. ATRFTIR spectroscopy study of the influence of $\mathrm{pH}$ and contact time on the adhesion of Shewanella putrefaciens bacterial cells to the surface of hematite. Environ. Sci. Technol. 2012, 46, 12848-12855.

(13) Jiang, W.; Saxena, A.; Song, B.; Ward, B. B.; Beveridge, T. J.; Myneni, S. C. B. Elucidation of functional groups on gram-positive and gram-negative bacterial surfaces using infrared spectroscopy. Langmuir 2004, 20, 11433-11442.

(14) Parikh, S. J.; Mukome, F. N. D.; Zhang, X. ATR-FTIR spectroscopic evidence for biomolecular phosphorus and carboxyl groups facilitating bacterial adhesion to iron oxides. Colloids Surf., $B$ 2014, 119, 38-46.

(15) Fang, L.; Cao, Y.; Huang, Q.; Walker, S. L.; Cai, P. Reactions between bacterial exopolymers and goethite: A combined macroscopic and spectroscopic investigation. Water Res. 2012, 46, 5613-5620.

(16) Zhang, M.; Ginn, B. R.; DiChristina, T. J.; Stack, A. G. Adhesion of Shewanella oneidensis MR-1 to iron (oxy) (hydr)oxides: Microcolony formation and isotherm. Environ. Sci. Technol. 2010, 44, 16021609.

(17) Chen, W.; Qian, C.; Liu, X.-Y.; Yu, H.-Q. Two-dimensional correlation spectroscopic analysis on the interaction between humic acids and $\mathrm{TiO}_{2}$ nanoparticles. Environ. Sci. Technol. 2014, 48, 1111911126.

(18) Zou, C.; Larisika, M.; Nagy, G.; Srajer, J.; Oostenbrink, C.; Chen, X.; Knoll, W.; Liedberg, B.; Nowak, C. Two-dimensional heterospectral correlation analysis of the redox-induced conformational transition in cytochrome $c$ using surface-enhanced raman and infrared absorption spectroscopies on a two-layer gold surface. J. Phys. Chem. B 2013, 117, 9606-9614.

(19) Chen, W.; Habibul, N.; Liu, X.-Y.; Sheng, G.-P.; Yu, H.-Q. FTIR and synchronous fluorescence heterospectral two-dimensional corre- 
lation analyses on the binding characteristics of copper onto dissolved organic matter. Environ. Sci. Technol. 2015, 49, 2052-2058.

(20) Yang, Y.; Yan, W.; Jing, C. Dynamic adsorption of catechol at the goethite/aqueous solution interface: a molecular-scale study. Langmuir 2012, 28, 14588-14597.

(21) Yan, W.; Zhang, J.; Jing, C. Adsorption of enrofloxacin on montmorillonite: two-dimensional correlation ATR/FTIR spectroscopy study. J. Colloid Interface Sci. 2013, 390, 196-203.

(22) Yan, W.; Hu, S.; Jing, C. Enrofloxacin sorption on smectite clays: effects of $\mathrm{pH}$, cations, and humic acid. J. Colloid Interface Sci. 2012, 372, 141-147.

(23) Noda, I. Two-dimensional correlation spectroscopy-Biannual survey 2007-2009. J. Mol. Struct. 2010, 974, 3-24.

(24) Claessens, J.; Behrends, T.; Van Cappellen, P. What do acidbase titrations of live bacteria tell us? A preliminary assessment. Aquat. Sci. 2004, 66, 19-26.

(25) Furukawa, Y.; Dale, J. R. The surface properties of Shewanella putrefaciens 200 and S. oneidensis MR-1: The effect of $\mathrm{pH}$ and terminal electron acceptors. Geochem. Trans. 2013, 14, 3-13.

(26) Barja, B. C.; Tejedor-Tejedor, M. I.; Anderson, M. A. Complexation of methylphosphonic acid with the surface of goethite particles in aqueous solution. Langmuir 1999, 15, 2316-2321.

(27) Barja, B. C.; Herszage, J.; Alfonso, M. D. Iron(III)-phosphonate complexes. Polyhedron 2001, 20, 1821-1830.

(28) Elzinga, E. J.; Kretzschmar, R. In situ ATR-FTIR spectroscopic analysis of the co-adsorption of orthophosphate and $\mathrm{Cd}(\mathrm{II})$ onto hematite. Geochim. Cosmochim. Acta 2013, 117, 53-64.

(29) Elzinga, E. J.; Sparks, D. L. Phosphate adsorption onto hematite: An in situ ATR-FTIR investigation of the effects of $\mathrm{pH}$ and loading level on the mode of phosphate surface complexation. J. Colloid Interface Sci. 2007, 308, 53-70.

(30) Kubicki, J. D.; Paul, K. W.; Kabalan, L.; Zhu, Q.; Mrozik, M. K.; Aryanpour, M.; Pierre-Louis, A.-M.; Strongin, D. R. ATR-FTIR and density functional theory study of the structures, energetics, and vibrational spectra of phosphate adsorbed onto goethite. Langmuir 2012, 28, 14573-14587.

(31) Liu, H.; Chen, T.; Qing, C.; Xie, Q.; Frost, R. L. Confirmation of the assignment of vibrations of goethite: An ATR and IES study of goethite structure. Spectrochim. Acta, Part A 2013, 116, 154-159.

(32) Buijs, J.; Norde, W.; Lichtenbelt, J. W. T. Changes in the secondary structure of adsorbed IgG and $\mathrm{F}\left(\mathrm{ab}^{\prime}\right)_{2}$ studied by FTIR spectroscopy. Langmuir 1996, 12, 1605-1613.

(33) Ishida, K. P.; Griffiths, P. R. Comparison of the Amide I/II intensity ratio of solution and solid-state proteins sampled by transmission, attenuated total reflectance, and diffuse reflectance spectromertry. Appl. Spectrosc. 1993, 47, 584-589.

(34) Gao, X.; Chorover, J. In-situ monitoring of cryptosporidium parvum oocyst surface adhesion using ATR-FTIR spectroscopy. Colloids Surf., B 2009, 71, 169-176.

(35) Jiang, W.; Yang, K.; Vachet, R. W.; Xing, B. Interaction between oxide nanoparticles and biomolecules of the bacterial cell envelope as examined by infrared spectroscopy. Langmuir 2010, 26, 18071-18077.

(36) O’Loughlin, E. J.; Gorski, C. A.; Scherer, M. M.; Boyanov, M. I.; Kemner, K. M. Effects of oxyanions, natural organic matter, and bacterial cell numbers on the bioreduction of lepidocrocite $(\gamma$ $\mathrm{FeOOH}$ ) and the formation of secondary mineralization products. Environ. Sci. Technol. 2010, 44, 4570-4576. 